\title{
A new species of Pimelodus LaCépède, 1803 (Siluriformes: Pimelodidae) from the rio São Francisco drainage, Brazil
}

\author{
Frank Raynner V. Ribeiro* and Carlos Alberto S. de Lucena**
}

\begin{abstract}
Pimelodus pohli, new species, is described from the rio São Francisco drainage. It differs from congeners by the following characters in combination: adults with dark spots on anterodorsal region of body and young specimens (up to $100 \mathrm{~mm} \mathrm{SL}$ ) with three rows of dark spots laterally on body; comparatively long adipose fin, more than one third of the distance between posterior end of dorsal fin base and the vertical through posterior end of anal-fin base (21.8-26.2\% SL); lips poorly developed; 20-25 gill rakers; and maxillary barbels slightly surpassing the caudal-fin base. A key to the species of Pimelodus of the rio São Francisco drainage is presented.
\end{abstract}

Pimelodus pohli, nova espécie, é descrita da bacia do rio São Francisco. Difere de suas congêneres pela seguinte combinação de caracteres: presença, em exemplares adultos, de pintas escuras na região ântero-lateral do corpo e, em exemplares jovens, de três fileiras de pintas nos lados do corpo (até $100 \mathrm{~mm} \mathrm{CP}$ ); nadadeira adiposa comparativamente longa, ocupando mais de um terço da distância entre o fim da base da nadadeira dorsal e a vertical que passa pelo fim da base da nadadeira anal (21,8-26,2\% CP); lábios não desenvolvidos; 20 a 25 rastros branquiais e barbilhões maxilares indo pouco além da base da nadadeira caudal. Uma chave para as espécies de Pimelodus da bacia do rio São Francisco é apresentada.

Key words: Catfish, Taxonomy, South America, Neotropical.

\section{Introduction}

The catfish family Pimelodidae encompasses 32 genera and 84 species distributed exclusively in freshwaters of the Neotropical Region from drainages of Panama, Central America to Argentina, South America (Lundberg \& Littmann, 2003).

Lundberg et al. (1991a) proposed a scheme of relationships among the genera of Pimelodidae. According to these authors within pimelodids there is a polytomic clade with 12 genera, including Pimelodus, which has been informally called "Pimelodus-group".

Within the "Pimelodus group", Lundberg et al. (1991a) and Lundberg \& Parisi (2002) identified one derived state of trigeminofacial nerve-complex (and respective foramina) that diagnose a core group of Pimelodus, including P. maculatus LaCépède, 1803, type species of the genus; P. blochii Valenciennes in Cuvier \& Valenciennes, 1840; P. coprophagus Schultz, 1944; P. grosskopfii Steindachner, 1879; P. jivaro Eigenmann \& Pearson, 1942; and P. pictus Steindachner, 1877. As those authors have pointed out, this character is not exclusive of that group, also occurring in Iheringichthys labrosus
(Lütken, 1974), Bergiaria westermanni (Lütken, 1874), and Cheirocerus abuelo (Schultz, 1944).

According to Lundberg \& Littmann, (2003) the genus is a non-monophyletic assemblage with ca 24 species and is defined by a set of non-derived morphological characters (see Mees, 1974, Burgess, 1989, and Britski et al., 1999). Species level taxonomy of Pimelodus is still poorly known as well as the phylogenetic relationships within and of the genus. The high number of species currently included in Pimelodus, allied to the wide variability in morphology and color pattern of those taxa, pose difficulties for a complete systematic revision of the genus, a task that is beyond of the scope of this study. Carrying out a regional revision is probably the only way to deal with this kind of problem.

Three species are cited for the São Francisco drainage: Pimelodus fur (Lütken, 1874), with type-locality in that same drainage, P. maculatus LaCépède, 1803, originally described from La Plata basin (Britski et al., 1988; Alves \& Pompeu, 2001) and a third undescribed species (see Britski et al. 1988). We herein describe the latter species and provide a key to the species of Pimelodus of the São Francisco drainage.

\footnotetext{
* Instituto Esperança de Ensino Superior, rua Coaracy Nunes, 3315, 68040100 Santarém, PA, Brazil. e-mail: frank@iespes.edu.br ** Laboratório de Ictiologia, Museu de Ciências e Tecnologia, Pontifícia Universidade Católica do Rio Grande do Sul, Av. Ipiranga 6681, 90619-900 Porto Alegre, RS, Brazil. e-mail: lucena@pucrs.br
} 


\section{Material and Methods}

Measurements and counts follow Lundberg \& McDade (1986) and Lundberg et al. (1991b) with the modifications of Lundberg \& Parisi (2002). Additional measurements include: (1) preadipose length measured from the insertion of the last dorsal-fin ray to adipose-fin origin; (2) urogenital-anal fin distance from urogenital papilla to anterior base of first anal-fin ray; (3) postcleithral process length measured from its base, near the insertion of the pectoral spine base, to its posteriormost tip; (4) supraoccipital width measured transversally on its base, and (5) supraoccipital length measured from its base to posteriormost tip.

Examined specimens belong to the Museu de Ciências e Tecnologia, Pontifícia Universidade Católica do Rio Grande do Sul, Porto Alegre (MCP), Museu de Zoologia da Universidade de São Paulo, São Paulo (MZUSP), Naturhistorisches Museum, Wien (NMW), National Natuurhistorisch Museum, Leiden (RMNH), Museo de La Plata, La Plata (MLP), Field Museum of Natural History, Chicago (FMNH), American Museum of Natural History, New York (AMNH), and Linha de Pesquisa em Ictiologia, Faculdades Integradas do Tapajós, Santarém (LPIFIT). Measurements are straight-line distances taken point-to-point with digital calipers to the nearest 0.1 $\mathrm{mm}$. Morphometric data for holotype is given separately in Table 1. All measurements are expressed as percents of standard length (SL), except subunits of the head that are expressed as percents of head length (HL).

Fin-ray counts include all rays. The two posteriormost anal-fin rays that are inserted at same base were counted as a single element. Gill rakers were counted on first branchial arch (ceratobranchial and hypobranchial). Vertebral counts (taken from two cleared specimens) include six elements in the Weberian complex. The first caudal vertebra is that immediately posterior to the visceral cavity. The compound caudal vertebra (PU1+U1) was counted as a single element.

\section{Results}

\section{Pimelodus pohli, new species}

Fig. 1

Pimelodus sp. - Britski et al., 1984: 31, 66 (key; description); Britski et al. 1986: 31, 66 (key; description); Britski et al., 1988: 31, 66 (key; description).

Holotype. MCP 38775, 150.0 mm SL, Brazil, Minas Gerais, rio

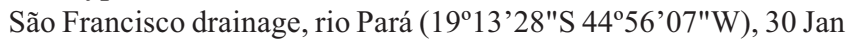
2005, José Enemir Santos.

Paratypes. MCP 37339, 1, 110.2 mm SL, Brazil, Minas Gerais: rio São Francisco, Três Marias reservoir (18³8'S 45ํ09'W), Jun 1989, Yoshimi Sato; MCP 14061, 1, $131.0 \mathrm{~mm}$ SL, rio São Francisco,

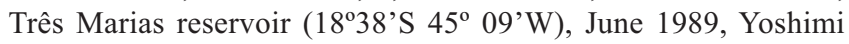
Sato; MCP 16668, 4, 69.3-85.3 mm SL, rio São Francisco drainage, rio Empoeirado (15³3'56"S 44²4'6"W), 13 Jul 1993, R. E. Reis, José P. Silva, Edson. L. Pereira \& S. Schaefer; MCP 37078, 8, 114.0-150.3 mm SL, near Três Marias reservoir, rio São Francisco,
Pompeu (19¹3'28"S 4456'07"W), 1 May 2004, José Enemir Santos; MCP 38776, 4, 121.9-139.1 mm SL, same as holotype; MZUSP 39320, 6, 95.0-121.7 mm SL, córrego do Cedro, rio São

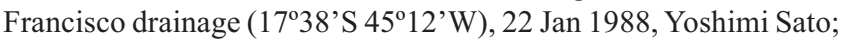
MCP 16661, 6, 44.3-105.7 mm SL, Bahia: rio São Francisco, Bom Jesus da Lapa $\left(13^{\circ} 15^{\prime} 12^{\prime \prime S} 43^{\circ} 25^{\prime} 20^{\prime \prime W}\right), 17$ Jul 1993, R. E. Reis, José P. Silva, Edson. L. Pereira \& S. Schaefer; MCP 16671, 7, 63.6$98.8 \mathrm{~mm} \mathrm{SL}, 2$ cleared and alizarin stained, 65.0-99.0 mm SL, rio São Francisco (13¹5’22"S 4326’51"W), 17 Jul 1993, R. E. Reis, José P. Silva, Edson. L. Pereira \& S. Schaefer; MZUSP 24704, 2, 128.7-134.3 mm SL, rio São Francisco, Juazeiro, Ilha Grande (09²5'S 40³1'W), 09 May 1975, M. de Brito; MZUSP 28782, 1, 99.8 mm SL, rio Desidério, rio São Francisco drainage, near Barreiras $\left(12^{\circ} 08^{\prime} \mathrm{S}\right.$ 4500’W), 2-6 May 1985, M. A. Cestarolli \& J. Camargo.

Diagnosis. Pimelodus pohli differs from its congeners by the following combination of characters: body deep (21.2$31.0 \%$ of SL); comparatively long adipose fin, occupying more than one third of the distance between posterior of the dorsal-fin base and vertical through the end of anal-fin base (21.8$26.2 \%$ of SL); upper jaw anteriorly projecting, exposing about half of the premaxillary tooth plate; the maxillary barbell slightly surpassing the caudal-fin base; supraoccipital process base broad (21.6-29.1\% of HL), bones of cranial roof ornamented with small granulations; narrow internarial anterior width 10.1$12.8 \%$ of HL; uniform gray color pattern, with few dark dots on anterolateral region of body in individuals greater than $100 \mathrm{~mm} \mathrm{SL}$ (sometimes weak or absent) and three or four rows of small dark dots on sides of body in smaller specimens; and a dark longitudinal bar on ventral lobe of the caudal fin, sometimes very faint. Two species of Pimelodus occur in the rio São Francisco drainage: $P$. fur and P. maculatus. Pimelodus pohli differs from the former by its shorter adipose-fin (21.8$26.2 \%$ vs $26.0-30.0 \% \mathrm{SL})$, deeper head (61.5-79.0\% vs 42.3 $50.2 \% \mathrm{HL})$; wider interorbital distance (21.9-30.4\% vs 12.1 $14.9 \% \mathrm{HL})$; wider anterior internarial distance $(10.1-12.8 \% v s$ 6.9-8.4\% HL); wider supraoccipital width (21.6-29.1\% vs 11.7$15.5 \% \mathrm{HL})$; longer snout (40.5-47.8\% vs $28.9-33.1 \% \mathrm{HL}$ ); dorsal supraoccipital process surface conspicuously ornamented with small granulations ( $v s$ supraoccipital with smooth surface). It differs from $P$. maculatus by its greater horizontal eye diameter (26.5-32.2\% vs 19.5-25.1\% HL) and by the peculiar color pattern of this species in all ontogenetic stages, consisting of three rows of dark spots ( $v s$ uniform gray color pattern, with a few darks dots on anterolateral region of the body, sometimes very weak or absent in individuals greater than $100 \mathrm{~mm} \mathrm{SL}$ ).

Pimelodus pohli can be differentiated from species of Pimelodus described from the adjacent Paraná-Paraguay-Uruguay River drainages. Pimelodus mysteriosus Azpelicueta, 1998 has a very long maxillary barbel that reaches the tips of caudal-fin lobes (Azpelicueta, 1998) (vs maxillary barbel short slightly surpassing the caudal-fin base in P. pohli). Pimelodus ortmanni Haseman, 1911, has dark spots on dorsal and caudal fins ( $v$ s absent in P. pohli). Pimelodus platicirris Borodin, 1927 and Pimelodus heraldoi Azpelicueta, 2001 have, respectively, three rows of spots and small dots irregularly placed 


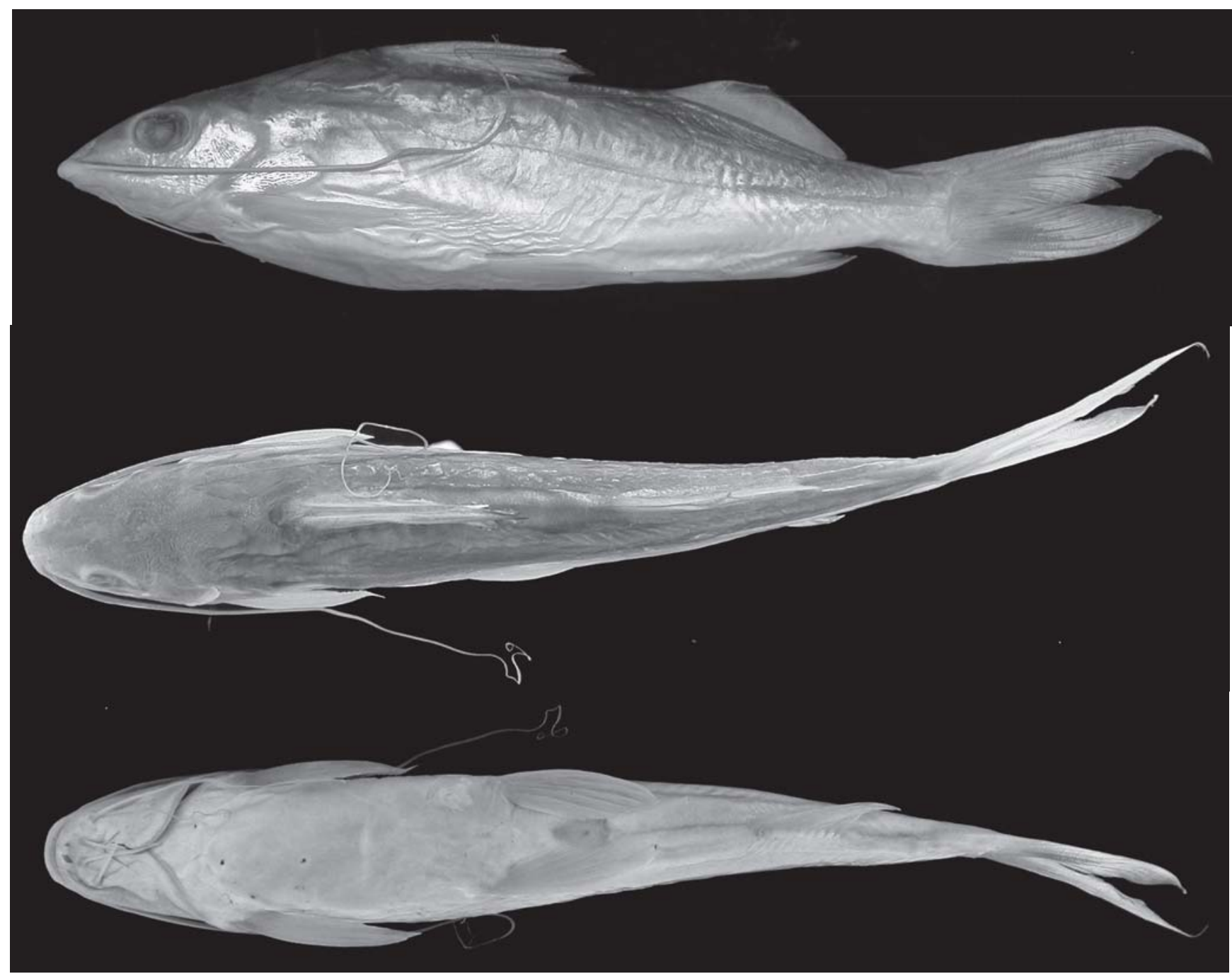

Fig. 1. Pimelodus pohli, new species. Holotype, rio Pará. rio São Francisco drainage, Minas Gerais, Brazil (MCP 38775, $150.0 \mathrm{~mm} \mathrm{SL}$ ). Lateral, dorsal view, and ventral views.

forming eight to nine rows on the lateral of body ( $v s$ dark spots when present restricted to the anterodorsal region of the body in specimens larger than $100 \mathrm{~mm}$ SL, in $P$.pohli). In addition $P$. platicirris has a relatively longer snout and $P$. heraldoi has striated lips (vs lips smooth in $P$. pohli) and smaller orbital diameter (19.4-26.0\% HL, Azpelicueta, 2001) (vs 26.5-32.2\% HL in P. pohli). Pimelodus paranaensis Britski \& Langeani, 1988 and Pimelodus absconditus Azpelicueta, 1995 also have small spots on the body sides, but $P$. pohli differs from the former in having the premaxillary tooth plate with rounded posterolateral corners (vs pointed in Pimelodus paranaensis, see Britski \& Langeani, 1988: fig. 3) and from the latter by the poorly developed lips ( $v s$ well developed in Pimelodus absconditus).

Description. Morphometric data of holotype and paratypes are presented in Table 1. Body deeper than wide. Dorsal profile of body convex from snout tip to dorsal-fin origin, straight from that region to adipose-fin origin gently declining to be- ginning of caudal peduncle. Dorsal and ventral profiles of caudal peduncle slightly concave. Ventral profile of head straight to anterior region of isthmus; ventral profile of body slightly convex to anal-fin origin; sloping dorsally along anal fin.

Head covered by thin skin. Skull roof ornamented with numerous small granulations, more visible in larger specimens. Snout not very long, projecting beyond mandibular symphysis by distance less than one vertical orbital diameter. Mouth subterminal; margins curved in ventral view when mouth is closed and exposing premaxillary tooth rows; upper lip thick, fleshy, not striated. Fleshy rictal fold in a pocket behind corner of mouth.

Distance between anterior and posterior nostrils shorter than distance between posterior nostril and anterior orbital margin; anterior nostril with fleshy rim slightly raised posteriorly; posterior nostril thin, fleshy, anteriorly elevated rim.

Eye large, elliptical, margin completely free and laterodorsally localized on head; horizontal orbital diameter usually greater than interorbital width $(0.7-1.1$, mean $=0.9)$; 


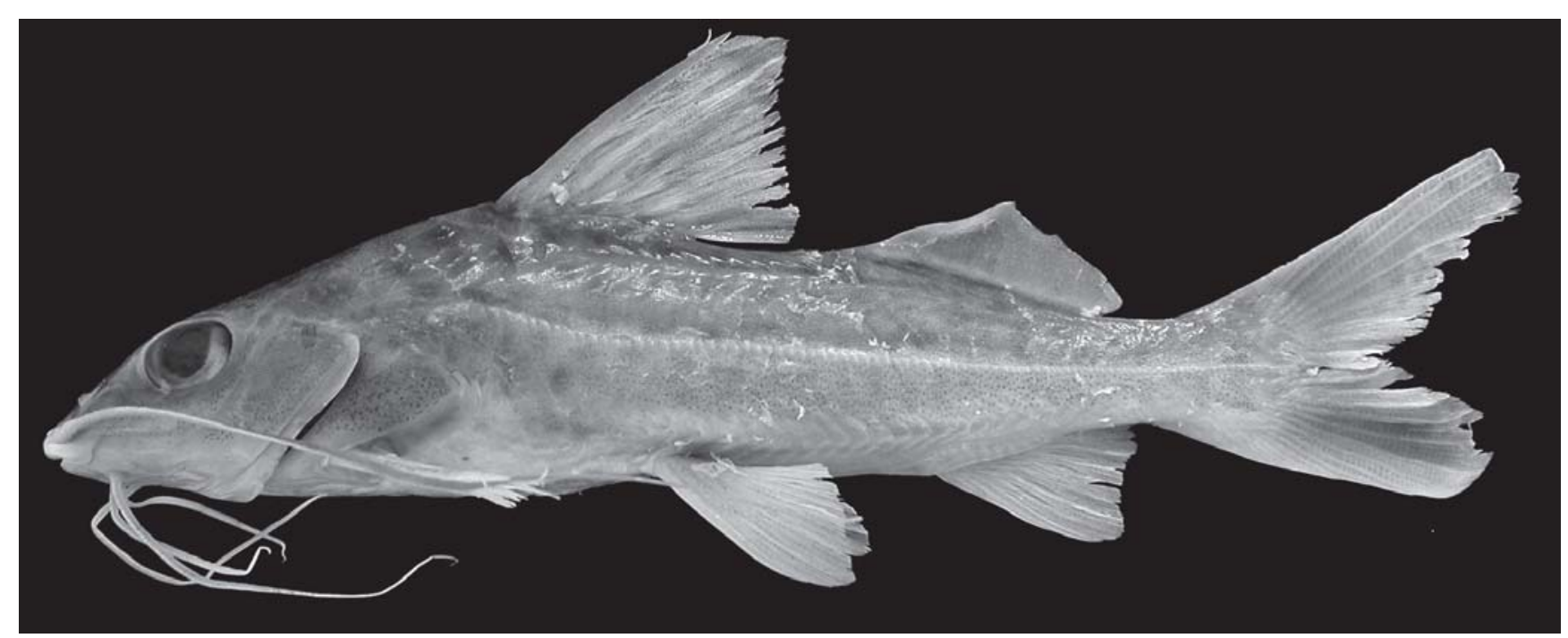

Fig. 2. Pimelodus pohli, new species. Paratype, rio Empoeirado, rio São Francisco drainage, Minas Gerais, Brazil (MCP 16668, $85.3 \mathrm{~mm} \mathrm{SL})$.

horizontal orbital diameter always greater than vertical orbital diameter.

Premaxillary tooth patch short, broad, rectangular and transversely elongated; each premaxilla with 6-8 irregular rows of conical and slender teeth. Dentary with 5-7 teeth rows. Vomerine teeth occasionally present, few conical teeth (one to five), smaller than those of jaws. Pterygoid tooth-plate absent.

Anterior cranial fontanel triangular in dorsal view, open from mesethmoid to frontals, and terminating before vertical through posterior margin of eye. Posterior cranial fontanel ovoid or circular foramen in center of supraoccipital in specimens smaller than $100 \mathrm{~mm}$ SL, and completely closed in larger specimens.

Supraoccipital process wide; dorsal surface ornamented with numerous small granulations; sides of supraoccipital process tapering posteriorly, covered by narrow band of opaque hyaline skin. Anterior and middle nuchal plates ornamented sparsely with tuberculated ridges. Anterior and middle nuchal plates ornamented sparsely with tuberculated ridges.

Three pairs of barbels, proximally compressed. Maxillary barbels inserted at vertical through anterior edge of lower jaw; slightly surpassing the caudal-fin base. All mental barbels inserted in advance of gular fold apex, in curved line parallel to mandibular margin. Inner mental barbels reaching base of pectoral fin. Tips of outer mental barbels reaching tips of middle pectoral-fin rays, almost to tip of pectoral spine. Gill membranes free, diverging at once from gular fold apex, supported by 8 branchiostegal rays.

Gill rakers well-ossified, sharp and slender; 20-25 (mean = 22) on first branchial arch; 4-7 on dorsal limb (mean = 5), 15-19 on ventral limb $($ mean $=17)(n=33)$.

Dorsal fin $(I, 6)$ inserted near in first third of SL; its origin slightly anterior to vertical through tip of innermost pectoralfin ray. Eight dorsal-fin rays: spinelet, spine, and 6 soft, branched rays $(n=33)$. Spinelet narrow, sharply angular or a low crest in front. Dorsal spine straight, strong, pungent, shorter than first branched ray, continued in filamentous ray reaching nearly edge of first soft dorsal-fin ray; approximately as long as to pectoral spine length. Dorsal spine with 1-3 anterior distal serrae. Posterior margin of dorsal spine moderate sharp retrorse spines distally, becoming gradually erect near spine base. First branched dorsal-fin ray longest, last dorsal-fin ray less than half-length of first ray; distal margin of dorsal fin nearly straight.

Adipose-fin large, slightly posterior to middle of body. Adipose-fin margin rounded and moderately deep, its apex near vertical through anal-fin origin, ending in short free lobe slightly posterior to vertical through terminus of anal-fin base.

Caudal fin (i, 7; 8,i) deeply forked, with pointed lobes; dorsal lobe slightly longer than ventral lobe, its outer principal rays non filamentous. Fifteen dorsal and 19 ventral procurrent caudal-fin rays $(n=2)$.

Anal fin inserted on second third of SL; fin margin concave, no forming distinct lobe in its anterior portion; tips of longest anterior and posterior rays meet when depressed. Anal fin iii-vi, $7-10($ mean $=8)(n=32)$, last rays simple, first branched ray longest.

Pectoral fin i,8-9; $($ mean $=9 ; n=33)$; its posterior margin obliquely truncate, first soft ray slightly longer than spine tip. Pectoral spine strong, distally pointed, dorsal and ventral surfaces smooth; numerous, regularly spaced, uniformly retrorse unicuspid dentations along most of posterior margin; anterior distal serrae weak or absent (commonly larger in juveniles), antrorse and straight dentations along proximal half of anterior margin, becoming progressively less prominent and more crowded proximally; anterior dentations much larger in juveniles.

Pelvic fin $(i, 5)$ first branched ray longest, inserted near vertical through fifth and sixth branched dorsal-fin ray. 
Table 1. Morphometric data of Pimelodus pohli, new species (H = Holotype, MCP 38775, 1 of MCP 37339, 1 of MCP 14061, 3 of MCP 16668, 8 of MCP 37078, 4 of MCP 38776; 6 of MZUSP 39320, 3 of MCP 16661, 3 of MCP 16671, 2 of MZUSP 24704, 1 of MZUSP 28782), $\mathrm{SD}=$ standard deviation. Range includes the holotype.

\begin{tabular}{lcccccc}
\hline \multicolumn{1}{c}{ Characters } & $\mathrm{H}$ & $\mathrm{n}$ & Low & Range & Mean & SD \\
\hline Standard length (mm) & 147.7 & 33 & 65.5 & 150.3 & & \\
& Percents of & standard length & & & \\
Predorsal length & 39.3 & 33 & 37.6 & 43.7 & 40.4 & 1.82 \\
Preanal length & 77.3 & 33 & 74.2 & 77.9 & 76.1 & 1.00 \\
Head length & 25.9 & 33 & 25.3 & 31.6 & 27.8 & 1.66 \\
Caudal peduncle length & 13.7 & 33 & 13.6 & 15.7 & 14.6 & 0.67 \\
Caudal peduncle depth & 9.8 & 33 & 8.2 & 10.0 & 9.1 & 0.46 \\
Adipose-fin length & 24.8 & 33 & 21.8 & 26.2 & 24.0 & 1.17 \\
Adipose-fin height & 5.8 & 33 & 5.2 & 8.3 & 6.6 & 0.73 \\
Preadipose length & 16.2 & 33 & 12.1 & 18.3 & 14.5 & 1.96 \\
Anal-fin base & 12.3 & 33 & 10.8 & 13.4 & 11.9 & 0.66 \\
Anal-fin length & 14.3 & 32 & 12.9 & 16.6 & 14.9 & 0.94 \\
Pelvic-fin length & 17.1 & 33 & 15.7 & 18.6 & 17.1 & 0.69 \\
Dorsal-fin length & 22.6 & 28 & 20.6 & 26.1 & 23.8 & 1.28 \\
Urogenital-anal fin distance & 16.3 & 33 & 12.2 & 18.2 & 14.2 & 1.39 \\
Dorsal-spine length & 21.8 & 29 & 16.8 & 25.1 & 21.9 & 1.53 \\
Pectoral-spine length & 17.3 & 30 & 17.0 & 22.0 & 19.1 & 1.14 \\
Body depth & 28.9 & 33 & 21.2 & 31.0 & 25.6 & 2.10 \\
Body width & 17.9 & 33 & 16.2 & 19.1 & 17.9 & 0.78 \\
Postcleithral process length & 12.0 & 33 & 11.5 & 13.9 & 12.6 & 0.67 \\
& Percents & of head length & & & \\
Head depth & 77.5 & 33 & 61.5 & 79.0 & 69.8 & 4.08 \\
Interorbital width & 30.4 & 33 & 21.9 & 30.4 & 25.7 & 2.51 \\
Snout length & 46.9 & 33 & 40.5 & 47.8 & 44.0 & 1.56 \\
Internarial length & 13.4 & 33 & 11.6 & 13.8 & 12.7 & 0.51 \\
Anterior internarial width & 12.0 & 33 & 10.1 & 12.8 & 11.5 & 0.72 \\
Posterior internarial width & 18.1 & 33 & 15.9 & 19.7 & 17.1 & 0.83 \\
Horizontal eye diameter & 27.0 & 33 & 26.5 & 32.2 & 29.1 & 1.63 \\
Mouth width & 29.3 & 33 & 27.2 & 36.0 & 30.2 & 1.80 \\
Supraoccipital width & 25.7 & 33 & 21.6 & 29.1 & 25.4 & 1.48 \\
Supraoccipital length & 40.1 & 33 & 31.2 & 40.2 & 35.8 & 2.08 \\
\hline
\end{tabular}

Lateral line canal complete, extending onto caudal-fin base, nearly straight, with superficial tubular ossicles directed posteroventrally and more developed anteriorly; no accessory laterosensory canals posterior to nuchal area.

Posterior cleithral process broad, triangular, with its ventral margin nearly straight, dorsal margin somewhat concave; granular and osseous tubercles on lateral surface.

Urogenital papilla short, located in shallow depression immediately behind anus between pelvic fins. No apparent sexual dimorphism.

Superficial ossifications of the Weberian complex centrum cover only partially the seventh centrum.

Total vertebrae 40-41 (16-17 precaudal and 24 caudal). First pleural rib on 6th vertebra. Ten pairs of ribs.

Color in alcohol. Ground body coloration gray, few dark dots on anterolateral region in individuals larger than $100 \mathrm{~mm} \mathrm{SL}$ (sometimes very weak or absent), three or four rows of small dark dots on sides of the body in smaller individuals (Fig. 2). Head surface with blackish areas. Venter light. Dorsal fin hyaline, black melanophores on interradial membranes, more conspicuous from median to distal region. Pectoral, pelvic and anal fins hyaline, sometimes base yellowish, interradial membranes scattered black melanophores. Adipose fin hyaline minute regularly scattered melanophores. Caudal fin hyaline to gently dusky, few black melanophores on interradial membranes; dark longitudinal bar on inferior lobe, sometimes very weak. Maxillary barbel dusky on dorsal surface; lighter on ventral surface. Mental barbels all light to yellowish. Several dark chromatophores on opercle and below orbit region.

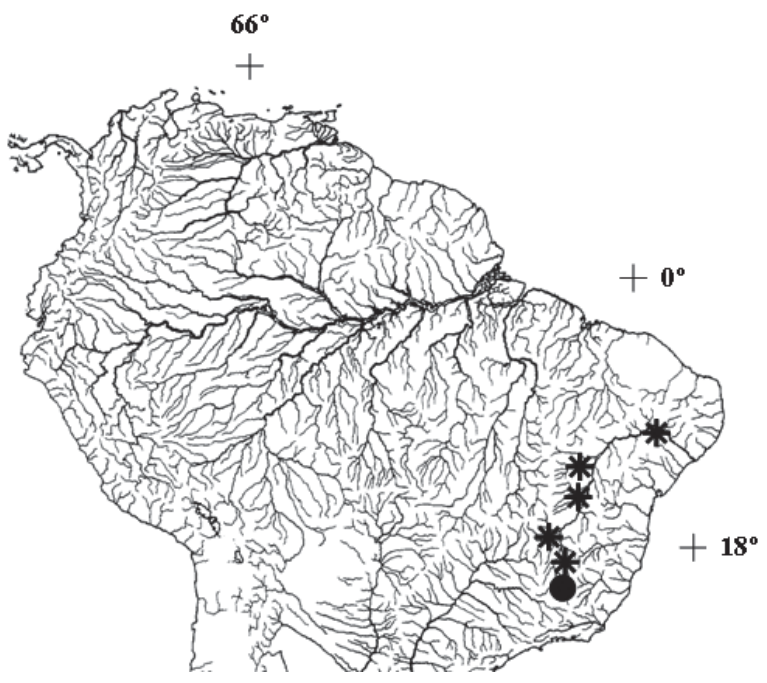

Fig. 3. Distribution of Pimelodus pohli (stars). Type-locality (circle). Symbols can represent more than one lot. 
Distribution. Pimelodus pohli is known from several localities along the rio São Francisco drainage, in the states of Minas Gerais and Bahia (Fig. 3).

Etymology. The specific name, pohli, in honor to Mr. Johan B. Emanuel Pohl whom, as participant of the Austrian Mission to Brazil (1817 to 1836) with Johann Natterer, collected in several localities of the rio São Francisco drainage.

Comments. Britski et al. $(1984 ; 1986 ; 1988)$ had identified as Pimelodus sp. a population that occurs in region of the Três Marias reservoir, rio São Francisco drainage. Examination of the specimens studied by Britski et al. (1988) revealed that these are indeed Pimelodus pohli. According to these authors Pimelodus sp. is very similar to Pimelodus blochii, a species with a large distribution range including the rio Amazonas basin and the majority of the cis-andean rivers from Northern South America. Pimelodus pohli is distinct from P. blochii, sensu Eigenmann (1912), both varieties A (body ashy, lateral line light; no spots) or B (body with four dark streak on the sides, the more ventral dark streak breaking into spots or absent at times), and from other species with the same distribution, by the characters given in the Diagnosis, specially the anterior internarial width (Fig. 4) and the color pattern.

Pimelodus pohli possess an enlarged posterior branch of the dorsal premaxillary process completely articulated with the anterolateral margin of mesethmoid. According to Azpelicueta (2001) this is a derived condition presented in $P$. heraldoi, P. fur, and P. absconditus only. On the other hand $P$. pohli does not share with these species the large anterior notch of mesethmoid; the short posterior process of the anguloarticular; and the elongate articular surface on the basioccipital for the internal branch of the supracleithrum, as illustrated by Azpelicueta (2001).

Cleared and stained specimens $(2,65.0-99.0 \mathrm{~mm} \mathrm{SL})$ show that the superficial ossifications of the Weberian complex centrum cover only partially the seventh centrum. The extent of exposition of vertebral centrum 7 has been used to diagnose species of Pimelodus. According to Azpelicueta (2001) it may be considered as a different ontogenetic state.

Key to the species of Pimelodus of the rio São Francisco drainage.

1. 15-18 rakers on first branchial arch; head depth 42.3-50.2\% HL; interorbital width $12.1-14.9 \%$ HL ........... Pimelodus fur

1'. 20-28 gill rakers on first branchial arch; head depth 58.6$79.0 \% \mathrm{HL}$; interorbital width $21.9-30.4 \% \mathrm{HL}$........................ 2

2. 25-28 rakers on first branchial arch; horizontal eye diameter $19.5-25.1 \% \mathrm{HL}$ Pimelodus maculatus

2'. 20-25 rakers on first branchial arch; eye diameter horizontal $26.5-32.2 \% \mathrm{HL}$ Pimelodus pohli, new species

Comparative material. Specific name is followed by catalogue number, number of specimens, range of standard length, $\mathrm{P}$ - photograph, CS - cleared and alizarin stained, and locality. Pimelodus

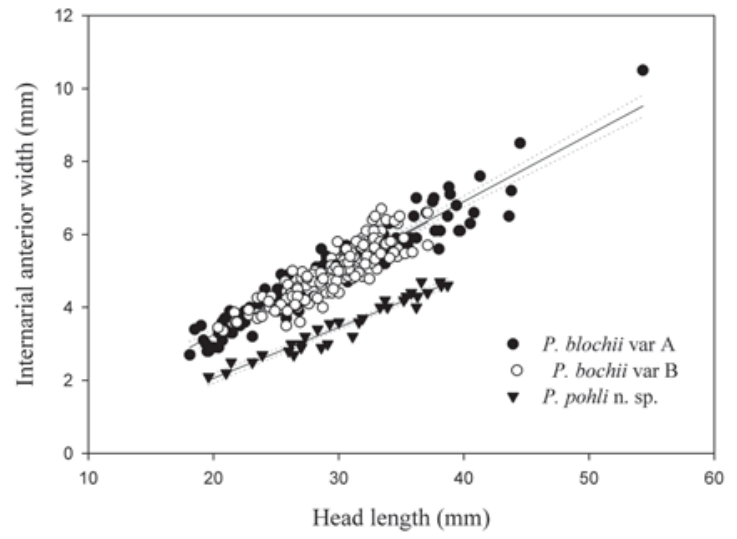

Fig. 4. Regression lines of internarial anterior width as a function of head length. Doted lines correspond to $90 \%$ confidence.

absconditus MCP 13392, 2, 129.3-133.7 mm, Brazil, rio Uruguay; MCP 12515, 1, $125.0 \mathrm{~mm}$, Brazil, rio Uruguay. Pimelodus albicans MCP 19248, 4, 139.9-199.6 mm, Argentina, rio Paraná. Pimelodus albofasciatus RMNH 26156, holotype, P, rio Sipaliwini, Suriname. Pimelodus altissimus MZUSP 24588, 1, $148.9 \mathrm{~mm}$, Brazil, rio Purus. Pimelodus cf. argenteus MCP 15811, 4, 53.5-166.5 mm, Brazil, rio Paraguai. Pimelodus atrobrunneus MCP 19678, holotype, $131.5 \mathrm{~mm}$, Brazil, rio Uruguay. Pimelodus blochii "variety A" LPIFIT 81, 3, 66.5-77.4 mm, Brazil, rio Amazonas; LPIFIT 147, (3) 4, 73.4-76.4 mm, Brazil, rio Amazonas; LPIFIT 176, (28) 33, 64.0-146.8 mm, Brazil, rio Amazonas; LPIFIT 197, $141.3 \mathrm{~mm}$, Brazil, rio Amazonas; MCP 20953, 1, 149.4 mm, Brazil, rio Amazonas; MCP 23987, (4) 11, 69.3-137.3 mm, Brazil, rio Amazonas, rio Madeira; MCP 24486, 2, 86.2-85.2 mm, Brazil, rio Amazonas; MCP 24598, (3) 5, 74.2-107.0 mm, Brazil, rio Amazonas, rio Jutaí; MCP 26237, 3, 78.4-136.1 mm, Brazil, rio Amazonas; MCP 34506, 2, 69.1-101.7 mm, Peru, rio Amazonas, rio Pacaya; MZUSP 6394, 2, 72.9-182.8 mm, Brazil, rio Amazonas, rio Purus; MZUSP 13504-13507, (2) 3, 130.5-160.6 mm, Brazil, rio Amazonas; MZUSP 23464, (3) 10, 103.3-124.6 mm, Brazil, rio Solimões; MZUSP 23523, (2) 7, 101.1-122.72 mm, Brazil, rio Amazonas; MZUSP 23555, (5) 13, 56.5-91.7 mm, Brazil, rio Amazonas, rio Japurá; MZUSP 30724, 3, 61.1-63.9 mm, Brazil, rio Amazonas, rio Madeira; MZUSP 30788, (5) 31, 78.8-99.5 mm, Brazil, rio Amazonas, rio Madeira; MZUSP 34512, (5) 8, 128.5159.8 mm, Brazil, rio Araguari; MZUSP 34513, 2, 151.3-154.0 $\mathrm{mm}$, Brazil, rio Amazonas, rio Xingu; MZUSP 50523, (2) 3, 114.2134.9 mm, Brazil, rio Amazonas, rio Juruá; MZUSP 50525, 1, 95.0 mm, Brazil, rio Amazonas, rio Juruá; MZUSP 54558, (5) 14, 75.1117.4 mm, Brazil, rio Amazonas, rio Tapajós; MZUSP 56448, (1) 3, 111.96 mm, Brazil, rio Amazonas; MZUSP 63177, (4) 18, Brazil, rio Amazonas, rio Cuiabá; MZUSP 74586, 1, 91.1 mm, Brazil, rio Solimões; MZUSP 74750, (10) 32, 75.2-126.7 mm, Brazil, rio Solimões; MZUSP 75659, (6) 22, 60.9-69.4 mm, Brazil, rio Solimões. Pimelodus blochii "variety B" LPIFIT 41, (8) 10, 110.0133.3 mm, Brazil, rio Tapajós; LPIFIT 98, (5) 6, 109.1-128.0 mm, Brazil, rio Tapajós; LPIFIT 112, 1, 106.0 mm, Brazil, rio Tapajós; LPIFIT 177, (14) 15, 68.9-108.7 mm, Brazil, rio Tapajós; LPIFIT 179, (1) 5, $133.8 \mathrm{~mm}$, Brazil, rio Tapajós; LPIFIT 180, 2, 98.4111.0 mm, Brazil, rio Tapajós; LPIFIT 185, 2, 103.1-121.9 mm, Brazil, rio Tapajós; LPIFIT 211, (1) 2, 107.6 mm, Brazil, rio Tapajós; LPIFIT 221, 2, 124.9-131.4 mm, Brazil, rio Tapajós; LPIFIT 227, 5, 95.5-120.0 mm, Brazil, rio Tapajós; LPIFIT 233, 6, 110.2-120.0 
mm, Brazil, rio Tapajós; LPIFIT 234, 8, 98.5-117.0 mm, Brazil, rio Tapajós; LPIFIT 236, (7) 8, 98.9-126.9 mm, Brazil, rio Tapajós; LPIFIT 239, (8) 9, 108.1-129.7 mm, Brazil, rio Tapajós; LPIFIT 241, 1, 118.0 mm, Brazil, rio Tapajós; LPIFIT 256, 9, 106.1-124.7 mm, Brazil, rio Tapajós; LPIFIT 266, 3 (4), 110.6-129.2 mm, Brazil, rio Tapajós; LPIFIT 268, (3) 4, 131.7-142.3 mm, Brazil, rio Tapajós; MCP 35831, 24, 94.0-132.7 mm, Brazil, rio Tapajós; MCP 36919, 12, 88.3-125.1 mm, Brazil, rio Tapajós; MCP 36920, 6, 98.5-127.0 mm, Brazil, rio Tapajós; MCP 36921, 3, 97.7-104.6 mm, Brazil, rio Tapajós; MCP 36922, 3, 108.8-123.2 mm, Brazil, rio Tapajós; MCP 36924, 3, 109.0-130.4mm, Brazil, rio Tapajós; MCP 36925, 2, 110.4-135.8 mm, Brazil, rio Tapajós; MCP 36926, 4, 108.8-123.2 mm, Brazil, rio Tapajós; MCP 39918, 12, 95.9130.7 mm, Brazil, rio Tapajós; MZUSP 24316, (2) 3, 128.6-134.3 mm, Brazil, rio Tapajós; MZUSP 30738, (3) 5, 87.3-101.1 mm, Brazil, rio Tapajós; MZUSP 46593, 1, 125.7 mm, Brazil, rio Tocantins; MZUSP 52323, 1, $100.5 \mathrm{~mm}$, Brazil, rio Tocantins, rio Araguaia; MZUSP 55731, 1, 88.5 mm, Brazil, rio Solimões; MZUSP 56473, 1, 99.2 mm, Brazil, rio Trombetas; MZUSP 56789, (5) 15, 99.7-122.8 mm, Brazil, rio Trombetas; MZUSP 57723, 1, 103.6 mm, Brazil, rio Tapajós; MZUSP 57741, 1, 96.2 mm, Brazil, rio Tapajós; MZUSP 57742, 2, 86.2-89.5 mm, Brazil, rio Tapajós; MZUSP 57743, 1, 90.8 mm, Brazil, rio Tapajós; MZUSP 57860, 1, 84.9 mm, Brazil, rio Madeira; MZUSP 57943, (3) 6, 99.2-114.8 mm, Brazil, rio Trombetas; MZUSP 57998, (2) 4, 81.1-86.6 mm, Brazil, rio Madeira; MZUSP 58144, 1, $83.2 \mathrm{~mm}$, Brazil, rio Amazonas; MZUSP 58165, 2, 112.1-114.8 mm, Brazil, rio Amazonas. Pimelodus fur MCP 14051, 4, 84.8-111.3 mm, Brazil, rio São Francisco; MCP 37328, 1, 123.2 mm, Brazil, rio São Francisco; MZUSP 39643, 11, 58.7-105.9 mm, Brazil, rio São Francisco. Pimelodus jivaro MZUSP 56729, 1, $93.3 \mathrm{~mm}$, CS, Brazil, rio Xingu; MZUSP 57672, 2, 90.9-92.5 mm, Brazil, rio Trombetas. Pimelodus heraldoi MZUSP 22713, holotype, 179.0 mm, P, Brazil, rio Mogi Guaçu, rio Paraná. Pimelodus maculatus MCP 16669 , 10, 77.1-137.1 mm, Brazil, rio São Francisco; MCP 16678, 1, 165.8 mm, Brazil, rio São Francisco; MCP 33817, 1, 69.1 mm, Brazil, rio São Francisco; MCP 33730, 3, 57.8-70.5 mm, Brazil, rio São Francisco; MCP 19249, 3, 56.7-102.0 mm, CS, Argentina, rio Paraná; MCP 13235, 1, 167.7 mm, Brazil, rio Uruguay; MZUSP 22980, 5, 62.5-118.6 mm, Brazil, rio São Francisco. Pimelodus microstoma NMW 45823, syntype, 1, Brazil, NMW 45824, syntypes, 2, 140.0125.8 mm, Brazil. Pimelodus mysteriosus MLP 9191, holotype, $103.0 \mathrm{~mm}, \mathrm{P}$, Argentina, arroio Anselmo. Pimelodus ornatus MCP 28870, 1, 90.7 mm, Brazil, rio Purus; MCP 15898, 1, 152.7 mm, Brazil, rio Tocantins. Pimelodus ortmanni FMNH 54240, holotype, $161.5 \mathrm{~mm}$, Brazil, rio Iguaçu. Pimelodus paranaensis MZUSP 23089, holotype, 235.0 mm, P, Brazil, rio Paraná. Pimelodus platicirris AMNH 8628, 1, 190.0 mm, P, Brazil, Rio Mogi Guaçu, rio Paraná. Pimelodus pictus MCP 29853, 1, 72.0 mm, Brazil, rio Solimões; MZUSP 25976, 1, 67.4 mm, Peru, rio Ucayali.

\section{Acknowledgments}

Museum study in São Paulo to FFR was supported by the All Catfish Species Inventory (NFS DEDB - 0315963). Osvaldo Oyakawa and José L. Figueiredo (MZUSP) for the support technician given to FFR during the visit to the collection under their care and for the loan of specimens; Helmut Wellendorf (NMW) for the loan of the syntypes of Pimelodus microstoma and photos. José Enemir dos Santos (PUC-MG) for the donation of specimens (Licença de Pesca Científica-
Categoria D - N. 006-B/04IEF, Instituto Estadual de Florestas). José P. da Silva (MCP) took the photos. This paper was greatly improved by the suggestions of three reviewers.

\section{Literature Cited}

Alves, C. B. M. \& Pompeu, P. dos S. 2001. A fauna de peixes da bacia do rio das velhas no final do século XX. Pp. 165-187. In: Alves, C. B. M \& P. S. Pompeu, (Org.) Peixes do rio das Velhas: passado e presente. Belo Horizonte, SEGRAC, 194p.

Azpelicueta, M. 1998. A new species of Pimelodus (Siluriformes: Pimelodidae) from the Paraguay and lower Paraná rivers. Neotropica, 44: 87-94.

Azpelicueta, M. 2001. A new species of Pimelodus (Siluriformes: Pimelodidae) from the upper Paraná basin, Brazil. Ichthyological Exploration of Freshwaters, 12(3): 193-200.

Britski, H. A. \& F. Langeani. 1988. Pimelodus paranensis sp.n., um novo Pimelodidae (Pisces, Siluriformes do alto Paraná, Brasil. Revista Brasileira de Zoologia, 5(3): 409-417.

Britski, H. A., Y. Sato \& R. Rosa. 1984. Manual de identificação de peixes da região de Três Marias. Brasília, Codevasf, 143p.

Britski, H. A., Y. Sato \& R. Rosa. 1986. Manual de identificação de peixes da região de Três Marias. ${ }^{\mathrm{a}}$. ed. Brasília, Codevasf, 115p.

Britski, H. A., Y. Sato \& R. Rosa. 1988. Manual de identificação de peixes da região de Três Marias. $3^{\text {a }}$. ed. Brasília, Codevasf, 115p.

Britski, H. A., K. Z. Silimon \& B. S. Lopes. 1999. Peixes do Pantanal: manual de identificação. Brasília, Embrapa, 184p.

Burgess, W. E. 1989. An atlas of freshwater and marine catfishes A preliminary survey of the Siluriformes. New Jersey, T. F. H. Publications, 784p.

Lundberg, J. G., A. H. Bornbusch \& F. Mago-Leccia. 1991. Gladioglanis conquistador N. Sp. from Ecuador with diagnoses of the subfamilies Rhamdiinae Bleeker and Pseudopimelodinae N. Subf. (Siluriformes: Pimelodidae). Copeia, 1991: 190-209.

Lundberg J. G., O. Linares, P. Nass \& M. E. Antonio 1988. Phractocephalus hemiliopterus (Pimelodidae, Siluriformes) from the upper Miocene Urumaco formation, Venezuela: a further case of evolutionary stasis and local extinction among South American fishes. Journal Vertebrate Paleontology, 8(2): 131-138.

Lundberg, J. G. \& M. W. Littmann. 2003. Family Pimelodidae (Longwhiskered catfishes). Pp. 432-446. In: Reis, E. R.; S. O. Kullander \& C. Ferraris Jr (Eds.). 2003. Check List of the Freshwater Fishes of South and Central America. Porto Alegre, Edipucrs. 729p.

Lundberg, J. G. \& L. A. McDade. 1986. On the South American catfish Brachyrhamdia imitator Myers (Siluriformes, Pimelodidae), with phylogenetic evidence for a large intrafamilial lineage. Notulae Naturae, 463:1-24.

Lundberg, J. G., F. Mago-Leccia \& P. Nass. 1991. Exalloduntus aguanai, a new genus and species of Pimelodidae (Pisces: Siluriformes) from deep river channels of South América, and delimitation of the subfamily Pimelodinae. Proceedings of the Biological Society Washington, 104 (4): 840-869.

Lundberg, J. G. \& B. M. Parisi. 2002. Propimelodus new genus, and redescription of Pimelodus eigenmanni Van der Stigchel 1946, a long-recognized yet poorly-known South American catfish (Pimelodidae: Siluriformes). Proceedings of the Academy of Natural Science, 152: 75-88.

Mees, G. F. 1974. The Auchenipteridae and Pimelodidae of Suriname (Pisces, Nematognathi). Zoologische Verhandelingen, 132:1-256.

Nass, P. 1991. Estúdio de la anatomia (osteologia, miologia y sistema nervioso) del bagre cunaguaro Brachyplatystoma juruense 
(Siluriformes, Pimelodidae). Unpublished Ph.D. Dissertation, Universidad Central de Venezuela, Caracas, 262p.

de Pinna, M. C. C. 1993. Higher-level phylogeny of Siluriformes (Teleostei, Ostariophysi, with a new classification of the order. Unpublished Ph.D. Dissertation, City University of New York, New York. 482p.

de Pinna, M. C. C. de. 1998. Phylogenetic relationships of Neotropical Siluriformes: historical overview and synthesis of hypotheses. Pp. 379-330. In: Malabarba, L. R., R. E. Reis, R. P. Vari, Z. M. S. Lucena, \& C. A. S. Lucena (Eds.). Phylogeny and Classification of Neotropical Fishes. Porto Alegre. Edipucrs, $603 \mathrm{p}$.

Submitted April 2006 Accepted September 2006 